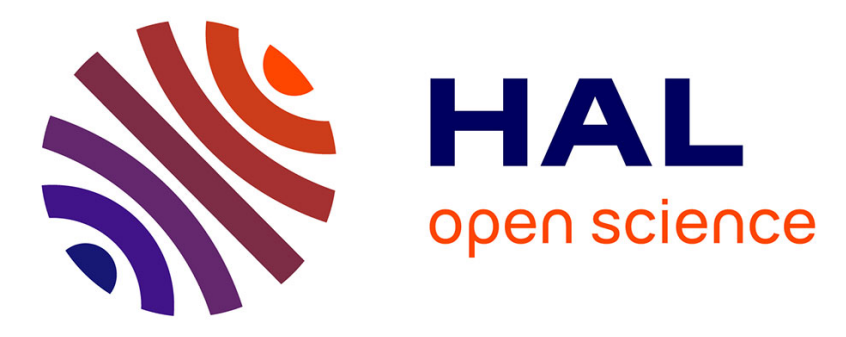

\title{
Preliminary study: A new method to assess the effective frontal area of cyclists
}

\author{
Anthony Bouillod, Luca Oggiano, Georges Soto-Romero, Emmanuel Brunet, \\ Frederic Grappe
}

\section{- To cite this version:}

Anthony Bouillod, Luca Oggiano, Georges Soto-Romero, Emmanuel Brunet, Frederic Grappe. Preliminary study: A new method to assess the effective frontal area of cyclists. 4th International Congress on Sport Sciences Research and Technology Support (IcSPORTS), Nov 2016, Porto, Portugal. hal01385084

\section{HAL Id: hal-01385084 \\ https://hal.science/hal-01385084}

Submitted on 20 Oct 2016

HAL is a multi-disciplinary open access archive for the deposit and dissemination of scientific research documents, whether they are published or not. The documents may come from teaching and research institutions in France or abroad, or from public or private research centers.
L'archive ouverte pluridisciplinaire HAL, est destinée au dépôt et à la diffusion de documents scientifiques de niveau recherche, publiés ou non, émanant des établissements d'enseignement et de recherche français ou étrangers, des laboratoires publics ou privés. 


\title{
Preliminary study: A new method to assess the effective frontal area of cyclists
}

\author{
Anthony Bouillod ${ }^{1,2,3}$, Luca Oggiano ${ }^{4}$, Georges Soto-Romero ${ }^{3,5}$, Emmanuel Brunet $^{2}$ and \\ Frederic Grappe ${ }^{1,6}$ \\ ${ }^{l}$ EA4660, C3S Health - Sport Department, Sports University, Besancon, France \\ ${ }^{2}$ French Cycling Federation, Saint Quentin en Yvelines, France \\ ${ }^{3}$ LAAS-CNRS, Université de Toulouse, CNRS, Toulouse, France \\ ${ }^{4}$ Norwegian university of science and technology - Department of energy and process engineering, Trondheim, Norway \\ ${ }^{5}$ ISIFC - Génie Biomédical, 23 Rue Alain Savary, Besançon, France \\ ${ }^{6}$ Professional Cycling Team FDJ, Moussy le Vieux, France \\ \{abouillo,gsotorom\}@laas.fr,luca.oggiano@ntnu.no,e.brunet@ffc.fr,frederic.grappe@univ-fcomte.fr
}

Keywords: $\quad$ Aerodynamics, 3D Scanning, CFD, Wind Tunnel, Field cycling.

\begin{abstract}
The present work aimed to assess the effective frontal area $\left(\mathrm{AC}_{\mathrm{d}}, \mathrm{m}^{2}\right)$ of a cyclist using both $3 \mathrm{D}$ scanning and Computational Fluid Dynamics (CFD) simulation and compare the results with wind tunnel and field measurements. One elite cyclist was recruited to complete a 3D scanning, a wind tunnel test and a field test. The 3D scanning was analyzed using CFD simulation to determine the $\mathrm{AC}_{\mathrm{d}}$ of the cyclist. The CFD $\mathrm{AC}_{\mathrm{d}}$ was compared to those measured in both wind tunnel and field tests. The 3D scanning method provides useful data for cycling science and TT position or equipment optimization, by using iterative approach. Indeed, the $\mathrm{AC}_{\mathrm{d}}$ obtained after CFD simulation was in accordance with those obtained in both wind tunnel and field testing sessions. Resolution, scanning time and post processing are compatible with an extensive use in real conditions and with a larger number of cyclists.
\end{abstract}

\section{INTRODUCTION}

Aerodynamic drag is the main resistance (80-90\%) among the total resistive forces $\left(\mathrm{R}_{\mathrm{T}}, \mathrm{N}\right)$ opposing motion on level ground in cycling (Debraux et al., 2011). To reduce air resistance, cyclists adopt a characteristic time trial (TT) position on the bicycle to decrease the effective frontal area $\left(\mathrm{AC}_{\mathrm{d}}\right.$, $\mathrm{m}^{2}$ ). The body of cyclist accounts for about $70 \%$ of the total drag while the remaining $30 \%$ is due to the bicycle frame and the components (Oggiano et al., 2008, Blocken et al., 2013). Thus, measures of a cyclist's ability to supply mechanical power do not always predict performance time in TT racing (Hoogeveen and Schep, 1997, Balmer, 2000). The cyclist position has a significant impact in the performance on flat terrain to overcome at the maximum the air resistance (Oggiano et al., 2008).
In order to optimize the position by reducing $\mathrm{AC}_{\mathrm{d}}$, experimental tests became common in cycling. The measurement techniques of $\mathrm{AC}_{\mathrm{d}}$ are now well recognised. This parameter can be reliably evaluated in laboratory or real cycling conditions (Debraux et al., 2011). The measures include wind tunnel tests (Davies, 1980, Garcia-Lopez et al., 2008, Martin et al., 1998), dynamometric (di Prampero et al., 1979, Capelli et al., 1993), deceleration (Candau et al., 1999) and linear regression (Grappe et al., 1997) methods. All of these have pros and cons. In addition to these methods, Computational Fluid Dynamics (CFD) simulations uses numerical analysis and algorithms to solve and analyze problems that involve fluid flows. Significant results from CFD simulations applied to cycling can be found in several studies (Defraeye et al., 2010a, Defraeye et al., 2010b, Defraeye et al., 2011, Blocken et 
al., 2013). While wind tunnel and field tests are able to provide the total $\mathrm{AC}_{\mathrm{d}}$ acting on the cyclist, CFD also provide drag information on individual body segments or bicycle components, increasing the insight in drag reduction mechanisms and allowing local modifications.

This study aimed to 1) assess the $A_{d}$ of a cyclist using both $3 \mathrm{D}$ scanning and CFD simulation and 2) compare the results with both wind tunnel and field measurements. In this preliminary analysis, we decided to leave out of account the effect of the bicycle on $\mathrm{AC}_{\mathrm{d}}$, and focus on the cyclist position.

\section{METHODS}

One elite cyclist was recruited to participate in the study. Prior to testing and after having received a full explanation of the nature and purpose of the study, the participant gave his written informed consents. The participant performed three testing sessions (3D scanning, wind tunnel test and field test) with the same roadracing bicycle (Look L96, Look Cycle International, Nevers, France).

\subsection{D Scanning}

Our focused application induces some technical specifications, among which:

- The scanned volume, including both cyclist and bicycle (around $4 \mathrm{~m}^{3}$ ).

- High resolution scanning (around $1 \mathrm{~mm}$ ), including ability to scan small details on equipment (bicycle frame, wheels, crank, helmet, skinsuit) or hard-to-reach places (like inside legs or under pedals areas). The resolution must also be compatible with a CFD meshing step.

- Different texture, colour and reflectance on unique scanning operation, including composite material, metal, textile, human skin, etc. No painting or irreversible operation on equipment were allowed.

- High speed scanning must be in accordance to the cyclist ability to stay in the same position (less than 10 minutes).

- Lightweight and portable equipment, in order to be packaged and carried according to cyclist availability.

By these considerations, contact scanners, scanning rooms and robotized arms with several scanners were excluded from tests. Photogrammetry was considered out of scope in this study.

Structured light scanners tested (Vialux, Chemnitz, Germany and Cobalt, Faro, Villepinte, France) in static position were unable to combine a high resolution and scanning volume specifications in a single operation. It would be necessary to perform several scanning and reconstruction, or to have several scanners operating in same time. However, this technique can be used to perform design and 3D printed prototyping for smaller parts, like helmets or handlebars.

At last, static laser scanner tested (Focus 3D, Faro, Villepinte, France) was unable to reach all the cyclist and bicycle areas in a single operation, because of masking the direct line of sight.

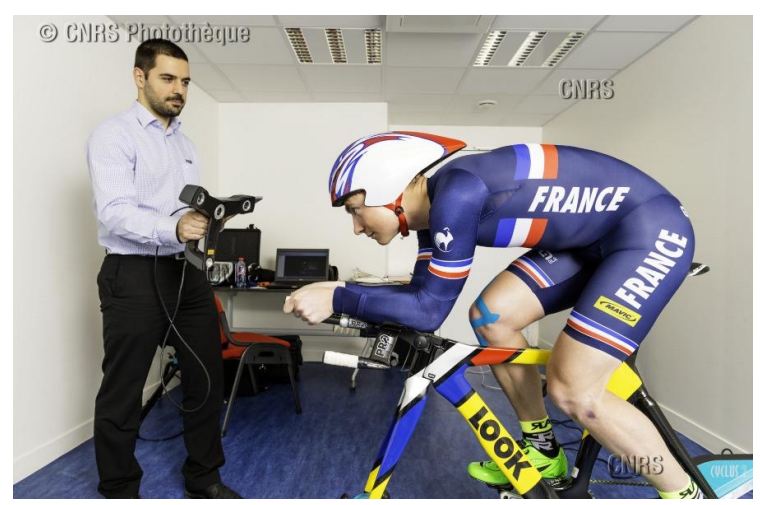

Figure 1: Picture of the 3D scanning setup.

Finally, the technical solution in accordance with specifications was a handle laser scanner (Freestyle 3D, Faro, Villepinte, France) with real time feedback by a scatter plot, resolution of $1 \mathrm{~mm}$ at 1 meter from scene, up to $8 \mathrm{~m}^{3}$ scene volume and less than $1 \mathrm{~kg}$. 


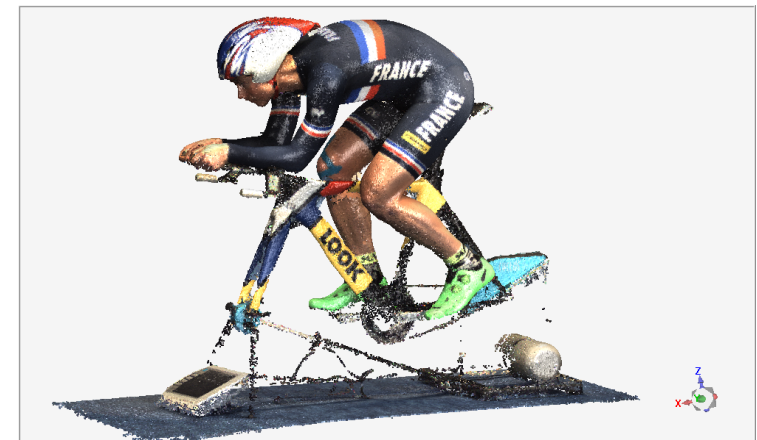

Figure 2: Model obtained with the Faro freestyle 3D.

This system could be used for both CFD modeling on bicycle parts, bicycle and rider profile, but also for mannequin or 3D printing parts. Reflective or composite parts could be treated with some caution for 3D scanning, sometimes by applying talcum powder on surfaces to improve quality of obtained scatter plot.

\subsection{CFD Simulation}

The CFD simulations was performed with the STARCCM+ solver from Cd-Adapco. The 3D model of the cyclist obtained from 3D scanning was imported into the software, the bicycle was digitally removed and the cyclist surface was discretized using a polyhedral surface mesh. A prismatic layer of 20 cells from the surface with the first cell placed so that a $\mathrm{y}+<1$ was achieved in the whole model was created in order to correctly resolve the boundary layer. The numerical wind tunnel consisted of a box with a cross section of $6 \times 6 \mathrm{~m}^{2}$ and a total length of $21 \mathrm{~m}$ (Blocken et al., 2013). The cyclist was placed at $3 \mathrm{~m}$ from the inlet and in the center of the test section. The k- $\varepsilon$ turbulence model, due to its ability to correcly model complex geometries, was used throughtout the simulations.

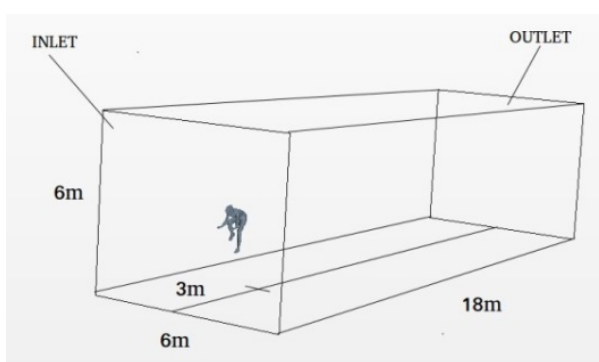

Figure 3: Numerical wind tunnel.

A steady state simulation as suggested by Blocken and Oggiano was used (Blocken et al., 2013, Defraeye et al., 2010a, Defraeye et al., 2010b, Defraeye et al., 2011, Oggiano et al., 2015). A dynamic Courant number approach was adopted in order to enhance convergence and reduce computational cost. Two different meshes were used in order to ensure grid independence, a coarse mesh consisting of ca.3.3millions cells and the reference mesh consisting of 5.5 millions cells. Velocity inlet and pressure outlet boundary conditions were used respectively for the inlet and the outlet. Symmetry plane boundary conditions were used in the sidewalls, top and bottom.

\subsection{Wind Tunnel Test}

A wind tunnel (up to $67 \mathrm{~m} . \mathrm{s}^{-1}$ ) was used to measure $\mathrm{AC}_{\mathrm{d}}$. It was a $3 / 4$ open circuit type with a nozzle section of $1.47 \mathrm{~m}$ high and $2.6 \mathrm{~m}$ wide and a testing section of $4.15 \mathrm{~m}$ high, $6.6 \mathrm{~m}$ wide and $9.3 \mathrm{~m}$ long, where a six-components force balance was placed (S2A, Montigny-le-Bretonneux, France). The force balance was circular $(2.8 \mathrm{~m}$ diameter) and equipped with strain gauges and force measurement systems. The bikes were placed on the force balance by means of 4 vertical supports for both front and rear wheel axles. Before the test, the force balance was calibrated. A first measurement was done with the bicycle only and a second measurement was done with the bicycle and the cyclist. After a 10-min warm-up, the cyclists pedalled at moderate intensity with a self-selected cadence at a 
wind speed of $50 \mathrm{~km} \cdot \mathrm{h}^{-1}$. Measurements were recorded over 30 s once the wind speed was stabilized (Garcia-Lopez et al., 2008).

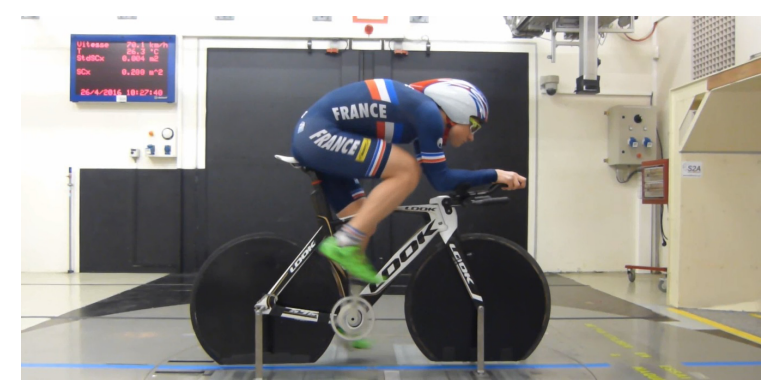

Figure 4: Picture of the cyclist during the wind tunnel test.

Main limits of wind tunnel measurements: the air flow around the bicycle is modified by the floor if the cyclist is motionless; the effect of the wind is altered if the wheels of the bicycle are stationary; the cyclist's position on the bicycle is not identical to the position in real cycling conditions (Candau et al., 1999); lateral sways that can occur in real cycling locomotion are not present in a wind tunnel.

\subsection{Field Test}

To determine the $\mathrm{AC}_{\mathrm{d}}$, the cyclist performed an incremental exercise at speeds $\left(\mathrm{V}, \mathrm{m} . \mathrm{s}^{-1}\right)$ from $30 \mathrm{~km} \cdot \mathrm{h}^{-1}$ to 50 $\mathrm{km} \cdot \mathrm{h}^{-1}$, increasing by $2 \mathrm{~km} \cdot \mathrm{h}^{-1}$ every $90 \mathrm{~s}$, on a $250 \mathrm{~m}$ covered velodrome (SaintQuentin-en-Yvelines, France). In order to avoid great variations of pedalling cadence, the gear ratio varied according to $\mathrm{V} . \mathrm{R}_{\mathrm{T}}$ was determined by the measurement of the power output $(\mathrm{PO}, \mathrm{W})$ at constant $\mathrm{V}$ on each increment as follows: $R_{T}=P O \cdot V^{-1}$. $R_{T}$ was plotted against $V^{2}$ to obtain the $R_{T}-V^{2}$ linear regression (Grappe et al., 1997). The equation of the linear regression to determine $A C_{d}$, using $R_{T}=\alpha V^{2}+\beta$, was $\mathrm{AC}_{\mathrm{d}}=\mathrm{a} / 0.5 \rho$ where $\rho\left(\mathrm{kg} \cdot \mathrm{m}^{-3}\right)$ is the air density. PO and $\mathrm{V}$ were measured by a SRM crankset (SRM, Schoberer Rad Messtechnich, Julich, Germany) and a speed sensor, respectively. The SRM power meter and the speed sensor were paired with a Garmin power control (Garmin 810, Olathe, USA). The data were analyzed with the use of the TrainingPeaks software (WKO4, Peaksware, Boulder, USA). A beeper was used to manage the pace during the whole exercise.

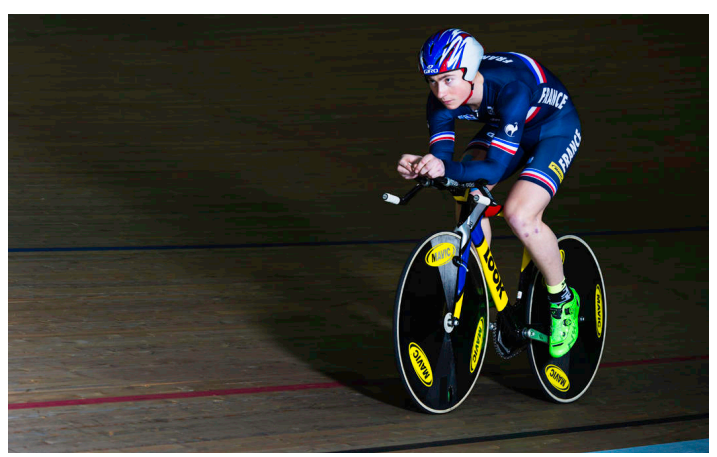

Figure 5: Picture of the cyclist during the field test.

\section{RESULTS AND DISCUSSION}

The $\mathrm{AC}_{\mathrm{d}}$ of the cyclist was assessed by combining both 3D scanning and CFD simulation, and the results were compared with both wind tunnel $\mathrm{AC}_{\mathrm{d}}$ and field $\mathrm{AC}_{\mathrm{d}}$.

The CFD simulation (figure 6) focused only on the cyclist, whereas wind tunnel test and field test considered the total $\mathrm{AC}_{\mathrm{d}}$. During both the wind tunnel test and the field test, we subtracted the $\mathrm{AC}_{\mathrm{d}}$ of the bicycle measured in the wind tunnel $(0.053$ $\mathrm{m}^{2}$ ) to obtain the $\mathrm{AC}_{\mathrm{d}}$ of the rider for each, and to compare them with the CFD $\mathrm{AC}_{\mathrm{d}}$.

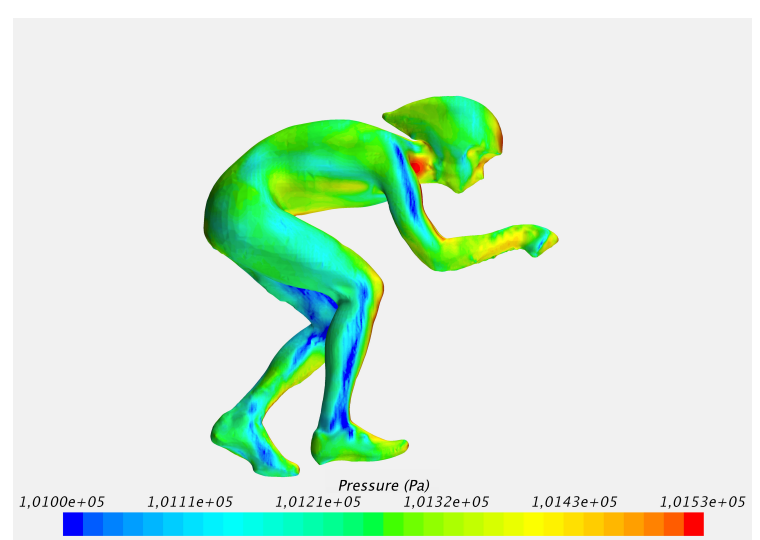

Figure 6: Pressure on the cyclist, computed by CFD simulation. 
The figure 7 shows that $\mathrm{AC}_{\mathrm{d}}$ of the cyclist obtained by wind tunnel test was lower than $\mathrm{AC}_{\mathrm{d}}$ computed by CFD simulation $(-10.9 \%)$. This result was in accordance with the literature and can be considered as a good agreement (Blocken et al., 2013, Oggiano et al., 2015). Additionally, $\mathrm{AC}_{\mathrm{d}}$ obtained by field test was lower than $\mathrm{AC}_{\mathrm{d}}$ computed by $\mathrm{CFD}$ simulation $(-13.1 \%)$ and the wind tunnel session $(-2.4 \%)$. This result was also in accordance with a previous study (GarciaLopez et al., 2014) which showed that total $\mathrm{AC}_{\mathrm{d}}$ was $0.003 \mathrm{~m}^{2}(1.3 \%)$ lower on the field when compared to wind tunnel.

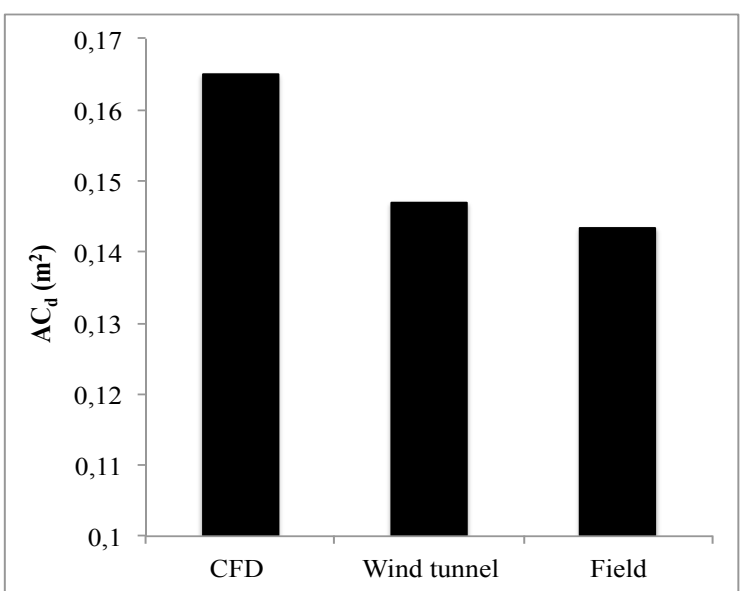

Figure 7: effective frontal area $\left(\mathrm{AC}_{\mathrm{d}}\right)$ of the cyclist obtained with the CFD, wind tunnel and field protocols.

\section{CONCLUSIONS}

Combining 3D scanning and CFD simulation methods provide useful data for cycling science and TT position optimization, despite of the big scanning volume and wide range of materials. Indeed, this preliminary study performed on one elite cyclist showed that combined 3D scanning and CFD simulation were in accordance with either wind tunnel or field measurements.

Resolution, scanning time and post processing are compatible with an extensive use in real conditions with a larger number of cyclists. This step could be used prior to wind tunnel step.

However, we also found some limits concerning bicycle and some equipment's scanning, specially on reflective parts, where the 3D scan by structured light give some shape errors.

\section{ACKNOWLEDGMENTS}

The authors would like to thank the participating cyclist (M.D. Geoffrey Millour) for his cooperation, as well as both companies, Kallisto, Toulouse and Faro, France for their support and scanner providing. We would also like to specially thank Dr. Antony Costes, for participating in preliminary tests as cyclist, and for his technical support. Last but not least, kind acknowledgements to Cyril Fresillon, for the accurate and honest touch of his photographic eye.

\section{REFERENCES}

BALMER, J. 2000. Peak power predicts performance power during an outdoor $16.1 \mathrm{~km}$ cycling time trial. Med Sci Sports Exerc, 32, 1485-1490.

BLOCKEN, B., DEFRAEYE, T., KONINCKX, E., CARMELIET, J. \& HESPEL, P. 2013. CFD simulations of the aerodynamic drag of two drafting cyclists. Computers \& Fluids, 71, 435445 .

CANDAU, R. B., GRAPPE, F., MENARD, M., BARBIER, B., MILLET, G. Y., HOFFMAN, M. D., BELLI, A. R. \& ROUILLON, J. D. 1999. Simplified deceleration method for assessment of resistive forces in cycling. Med Sci Sports Exerc, 31, 1441-7.

CAPELLI, C., ROSA, G., BUTTI, F., FERRETTI, G., VEICSTEINAS, A. \& DI PRAMPERO, P. E. 1993. Energy cost and efficiency of riding aerodynamic bicycles. Eur J Appl Physiol Occup Physiol, 67, 144-9.

DAVIES, C. T. 1980. Effect of air resistance on the metabolic cost and performance of cycling. Eur J Appl Physiol Occup Physiol, 45, 245-54.

DEBRAUX, P., GRAPPE, F., MANOLOVA, A. V. \& BERTUCCI, W. 2011. Aerodynamic drag in cycling: methods of assessment. Sports Biomechanics, 10, 197-218.

DEFRAEYE, T., BLOCKEN, B., KONINCKX, E., HESPEL, P. \& CARMELIET, J. 2010a. Aerodynamic study of different cyclist 
positions: CFD analysis and full-scale windtunnel tests. J Biomech, 43, 1262-8.

DEFRAEYE, T., BLOCKEN, B., KONINCKX, E., HESPEL, P. \& CARMELIET, J. $2010 \mathrm{~b}$. Computational fluid dynamics analysis of cyclist aerodynamics: performance of different turbulence-modelling and boundary-layer modelling approaches. $J$ Biomech, 43, 2281-7.

DEFRAEYE, T., BLOCKEN, B., KONINCKX, E., HESPEL, P. \& CARMELIET, J. 2011. Computational fluid dynamics analysis of drag and convective heat transfer of individual body segments for different cyclist positions. $J$ Biomech, 44, 1695-701.

DI PRAMPERO, P. E., CORTILI, G., MOGNONI, P. \& SAIBENE, F. 1979. Equation of motion of a cyclist. J Appl Physiol Respir Environ Exerc Physiol, 47, 201-6.

GARCIA-LOPEZ, J., OGUETA-ALDAY, A., LARRAZABAL, J. \& RODRIGUEZMARROYO, J. A. 2014. The use of velodrome tests to evaluate aerodynamic drag in professional cyclists. Int J Sports Med, 35, 4515.

GARCIA-LOPEZ, J., RODRIGUEZ-MARROYO, J. A., JUNEAU, C. E., PELETEIRO, J., MARTINEZ, A. C. \& VILLA, J. G. 2008. Reference values and improvement of aerodynamic drag in professional cyclists. J Sports Sci, 26, 277-86.

GRAPPE, F., CANDAU, R., BELLI, A. \& ROUILLON, J.-D. 1997. Aerodynamic drag in field cycling with special reference to the Obree's position. Ergonomics, 40, 1299-1311.

HOOGEVEEN, A. R. \& SCHEP, G. 1997. The plasma lactate response to exercise and endurance performance: relationships in elite triathletes. Int $J$ Sports Med, 18, 526-30.

MARTIN, J. C., MILLIKEN, D. L., COBB, J. E., MCFADDEN, K. L. \& COGGAN, A. R. 1998. Validation of a mathematical model for road cycling power. Journal of applied biomechanics, 14, 276-291.

OGGIANO, L., LEIRDAL, S., SAETRAN, L. \& ETTEMA, G. Aerodynamic optimization and energy saving of cycling postures for international elite level cyclists. ISEA Conference, 2008 Biarritz.

OGGIANO, L., SPURKLAND, L., BARDAL, L. M. \& SÆTRAN, L. Aerodynamical Resistance in Cycling - CFD Simulations and Comparison with Experiments. Proceedings of the 3rd International Congress on Sport Sciences Research and Technology Support, 2015 Lisbon, Portugal. 183-189. 